\title{
X-Ray Crysatllographic and Vibrational Spectroscopic Studies of Thorium Bromate Hydrate
}

\author{
M. Junaid Bushiri ${ }^{*}$, T. C. Kochuthresia ${ }^{2}$, S. Athimoolam ${ }^{3}$, V. Ramakrishnan ${ }^{4}$, V. K. Vaidyan ${ }^{2}$ \\ ${ }^{1}$ Department of Physics, Cochin University of Science and Technology, Kochi, India \\ ${ }^{2}$ Department of Physics, University of Kerala, Thiruvananthapuram, India \\ ${ }^{3}$ Department of Physics, University College of Engineering, Anna University Tirunelveli Region, \\ Nagercoil, India \\ ${ }^{4}$ School of Physics, Madurai Kamaraj University, Madurai, India \\ Email: ${ }^{*}$ junaidbushiri@cusat.ac.in
}

Received November 30, 2012; revised January 1, 2013; accepted January 10, 2013

Copyright (C) 2013 M. Junaid Bushiri et al. This is an open access article distributed under the Creative Commons Attribution License, which permits unrestricted use, distribution, and reproduction in any medium, provided the original work is properly cited.

\begin{abstract}
$\mathrm{Th}\left(\mathrm{BrO}_{3}\right)_{3} \cdot \mathrm{H}_{2} \mathrm{O}$ single crystals were grown from its aqueous solution at room temperature. Single crystal XRD, Raman and FTIR techniques were used to investigate the crystal structure. The crystal structure was solved by Patterson method. The as grown crystals are in monoclinic system with space group P21/c. The unit cell parameters are $a=$ $12.8555(18) \AA, b=7.8970(11) \AA, c=9.0716(10) \AA, \alpha=90^{\circ}, \beta=131.568^{\circ}$ and $\gamma=90^{\circ}$ and unit cell volume is $689.1(2)$ $\AA^{3} . Z=8, R$ factor is 5.9. The Raman and FTIR studies indicate the lowering of symmetry of bromate anion from $C_{3 \mathrm{~V}}$ to $\mathrm{C}_{1}$. Hydrogen bonds with varying strengths are present in the crystal. The centrosymmetric space group P21/c of the crystal is confirmed by the non-coincidence of majority of Raman and IR bands.
\end{abstract}

Keywords: Thorium Bromate; X-Ray Diffraction; IR Spectroscopy; Raman; Crystal Structure; $\mathrm{BrO}_{3}^{-}$Anion

\section{Introduction}

Hydrated bromates, coordinated to rare earth metals are an interesting group of compounds due its magnetic and optical properties [1,2]. Further, Bromates are attained considerable interest from chemists because its role in chemical oscillator systems and chemiluminescence systems and as an oxidizing agent for the fast oxidation of secondary alcohols [3-7]. Recently, Thionine-Bromate is identified as a new reaction system for kinetic spectrophotometric determination of hydrazine in cooling tower water samples [8]. However a limited attention is paid by researchers to understand structural and physical properties of bromate compounds. Single crystal XRD and vibrational spectroscopic techniques are being used by different authors for elucidating structure of hydrated metallic bromates [9-15]. Interestingly, most of these compounds having hydrogen bonded crystalline structure and oxyhalogen anions in these compounds posses distorted pyramidal structure. Thorium is one of the important actinide elements, actinide bromate compounds are rarely reported in the literature. In the present work we are re-

${ }^{*}$ Corresponding author. porting structural studies of hydrated rare earth thorium bromate by using X-ray diffraction, Raman and infrared spectroscopy for the first time.

\section{Experimental}

Crystals used in the present investigation were grown from aqueous solution of thorium bromate by slow evaporation at room temperature $\left(32^{\circ} \mathrm{C}\right)$ over a period of one month. Single crystal X-ray diffraction data were collected by using single crystal X-ray diffractometer sealed tube CAD4/MACH3, with MoKa radiation $(\lambda=$ $0.71073 \AA$ ). CAD4 Software. Version 5.0. Enraf-Nonius were used for data collection [16,17]. The cell data were obtained from the least-squares refinement. Structure was solved by using ShellX97 program. Raman spectrum of the sample was recorded using Bruker RFS 100/s Raman spectrometer equipped with Nd:YAG laser (Wavelength $1064 \mathrm{~nm}$ at a Laser power of $150 \mathrm{~mW}$ ) in the stokes region from $50-4000 \mathrm{~cm}^{-1}$ with a spectral resolution better than $4 \mathrm{~cm}^{-1}$. Standard Ge detector was used for detecting the Raman signals. FTIR spectrum of the sample in the range $400-4000 \mathrm{~cm}^{-1}$ was obtained from Shimadzu spectrometer by $\mathrm{KBr}$ pellet method and in the region 50 - 
$400 \mathrm{~cm}^{-1}$ with polyethylene pellet method by using MAGNA 550 FTIR spectrometer.

\section{Results and Discussion}

\subsection{X-Ray Crystal Structural Studies}

The structure of the title compound is solved by Patterson method [16]. Thorium atoms are coordinated to oxygen atoms and some of these are coordinated to bromine and $\mathrm{H}_{2} \mathrm{O}$ (Figure 1). The average bond length of water (oxygen) coordinated $\mathrm{Th}(1)-\mathrm{O} 1 \mathrm{w}$ is of the order of 2.6972(0.0232) $\AA$ which is comparable to Th-O (water) distance $(2-46 \AA)$ reported in thorium nitrate pentahydrate [18]. The thorium atom coordinated to the oxygen atoms of bromate group ( $\mathrm{Th}(1)-\mathrm{O}\left(\right.$ of $\left.\mathrm{BrO}_{3}\right)$ is of the order of $2.7766(0.0125) \AA$. Generally lanthanide hydrated bromates form disordered bromate anions at room temperature [15]. In the actinide bromate also disordered bromate anion is seen which is formed by the bonding of oxygen atoms with bromine and Thorium atoms is shown in the ORTEP diagram (Figure 2). The average $\operatorname{Br}(1)$ $\mathrm{O}(1)$ distance is $1.6504(0.0133) \AA, \mathrm{Br}(1)-\mathrm{O}(3)$ is $1.6573(0.0129) \AA$ and $\operatorname{Br}(1)-\mathrm{O}(2) 1.6712(0.0128) \AA$ (Table 1). These distances are consistent with those of previously reported one in the literature [12-14].

\subsection{Raman and FTIR Spectral Studies}

$\mathrm{Th}\left(\mathrm{BrO}_{3}\right)_{3} \cdot \mathrm{H}_{2} \mathrm{O}$ crystallizes in the monoclinic crystal

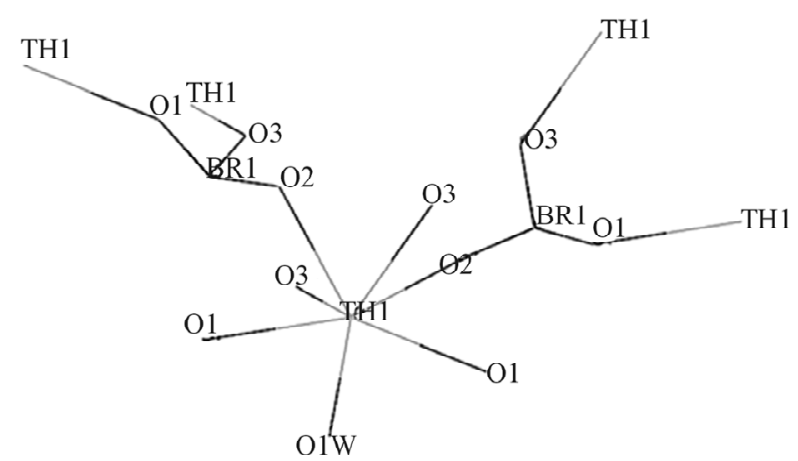

Figure 1. ORTEP diagram of hydrated thorium bromate.
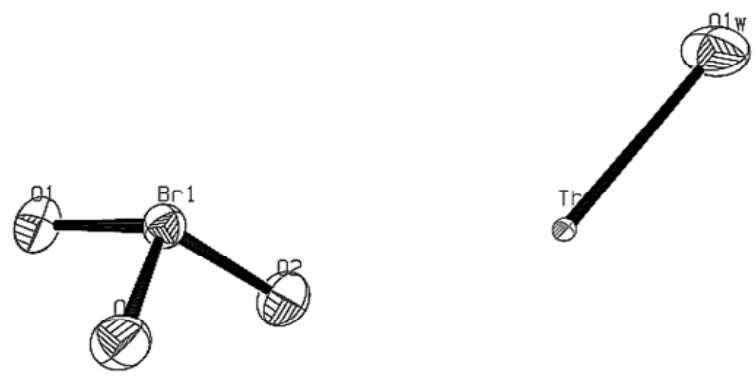

Figure 2. $\mathrm{BrO}_{3}^{-}$anion and thorium water coordination in hydrated thorium bromate. system (space group $\mathrm{P} 21 / \mathrm{c}, \mathrm{Z}=8$ ) and all the atoms are occupying in the $C_{1}$ sites. The factor group analysis was carried out by the correlation method developed by Fateley et al. [19]. The total irreducible representation, excluding the acoustic modes, are distributed as

$$
\Gamma 189=48 \mathrm{~A}_{\mathrm{g}}+48 \mathrm{~B}_{\mathrm{g}}+47 \mathrm{~A}_{\mathrm{u}}+46 \mathrm{~B}_{\mathrm{u}} .
$$

The $\mathrm{BrO}_{3}^{-}$anion with $\mathrm{C}_{3 \mathrm{~V}}$ symmetry has four fundamental modes of vibrations, symmetric stretching $v_{1}-$ $805\left(\mathrm{~A}_{1}\right)$, asymmetric stretching $v_{3}-805(\mathrm{E})$, symmetric bending $v_{2}-418\left(\mathrm{~A}_{1}\right)$ and asymmetric bending $v_{4}-358$ (E) $\mathrm{cm}^{-1}[13,14,16-20]$. For $\mathrm{XY}_{3}$ pyramidal $\left(\mathrm{C}_{3 \mathrm{v}}\right)$ molecules $\Gamma=2 \mathrm{~A}_{1}+2 \mathrm{E}$, and all the modes are active both in the Raman and IR spectra [20]. In Raman spectrum, a strong band is observed at $820 \mathrm{~cm}^{-1}$ followed by a shoulder at $796 \mathrm{~cm}^{-1}$ and another strong band is appeared at $784 \mathrm{~cm}^{-1}$ (Figure 3). The strongest band observed in the IR spectrum is at 789 followed by a strong shoulder at $821 \mathrm{~cm}^{-1}$. These bands correspond to $v_{1}-v_{3}$ modes of $\mathrm{BrO}^{3-}$ anion. These spectral band positions are in the same region as reported previously in the literature which is having comparable $\mathrm{Br}-\mathrm{O}$ distance [21-25]. The symme-tric stretching frequency of $\mathrm{BrO}_{3}^{-}$anion observed in this crystal is almost similar $\left(784 \mathrm{~cm}^{-1}\right)$ to that of reported in crystals like $\mathrm{Cd}\left(\mathrm{BrO}_{3}\right)_{2} \cdot 2 \mathrm{H}_{2} \mathrm{O}, \mathrm{Nd}\left(\mathrm{BrO}_{3}\right)_{3} \cdot 9 \mathrm{H}_{2} \mathrm{O}$, $\mathrm{Gd}\left(\mathrm{BrO}_{3}\right)_{3} \cdot 9 \mathrm{H}_{2} \mathrm{O}$ and $\mathrm{La}\left(\mathrm{BrO}_{3}\right)_{3} \cdot 9 \mathrm{H}_{2} \mathrm{O}$ [23-26]. This

Table 1. Selected bond distances of thorium bromate hydrate.

\begin{tabular}{cc}
\hline $\mathrm{Br}(1)-\mathrm{O}(1)$ & $1.6504(0.0133) \AA$ \\
\hline $\mathrm{Br}(1)-\mathrm{O}(2)$ & $1.6712(0.0128) \AA$ \\
$\mathrm{Br}(1)-\mathrm{O}(3)$ & $1.6573(0.0129) \AA$ \\
$\mathrm{Th}(1)-\mathrm{O}(1) \mathrm{w}$ & $2.6972(0.0232) \AA$ \\
$\mathrm{Th}(1)-\mathrm{O}\left(\mathrm{of} \mathrm{BrO}_{3}\right)$ & $2.7766(0.0125) \AA$ \\
\hline
\end{tabular}

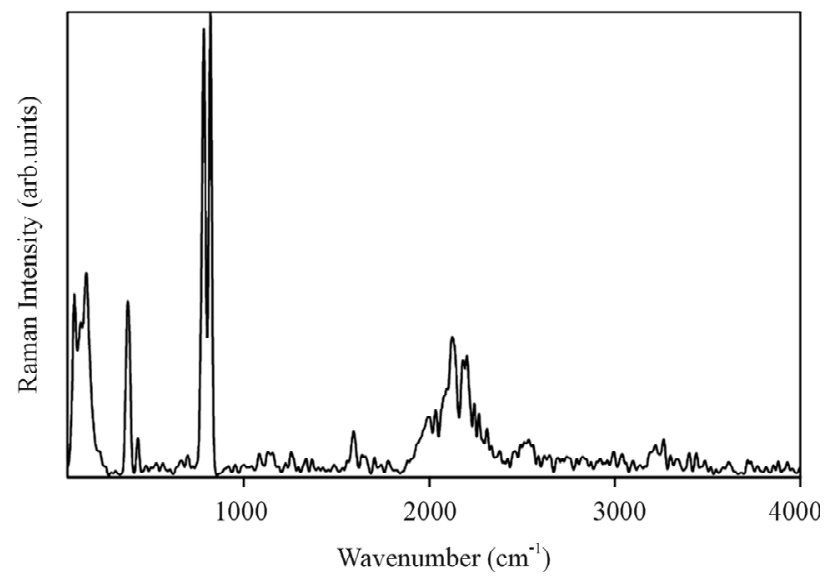

Figure 3. FT Raman spectrum of hydrated thorium bromate in the region $50-4000 \mathrm{~cm}^{-1}$. 
downward shift is attributed to the presence of hydrogen bonding, which is attached to water molecules.

Symmetric bending mode $v_{2}$ is observed at $429 \mathrm{~cm}^{-1}$ as a weak band in the Raman spectrum similar to that in the case of $\left[\mathrm{Cu}\left(\mathrm{H}_{2} \mathrm{O}\right)_{6}\right]\left(\mathrm{BrO}_{3}\right)_{2}$ (Table 2) [25]. The degeneracy of the $v_{4}$ mode of $\mathrm{BrO}_{3}^{-}$anion is lifted in the Raman spectrum and two bands are observed at 371 and at $383 \mathrm{~cm}^{-1}$ (Figure 3). Lifting of degeneracy is also observed in the IR spectrum and two bands are observed at 363 and $389 \mathrm{~cm}^{-1}$. The lifting of degeneracy of $v_{4}$ mode both in the Raman and IR spectra indicate the lowering of symmetry of $\mathrm{BrO}_{3}^{-}$anion from $\mathrm{C}_{3 \mathbf{v}}$ pyramidal to lower one at $\mathrm{C}_{1}$. A moderately intense broad band is observed at $152 \mathrm{~cm}^{-1}$ in Raman spectra is assigned to the $\mathrm{BrO}_{3}^{-}$rotational mode [27].

Table 2. Raman and IR Spectral data of thorium bromate hydrate $\left(\mathrm{cm}^{-1}\right)$.

\begin{tabular}{|c|c|c|}
\hline Raman & IR & Assignments \\
\hline $85 \mathrm{~ms}$ & $\begin{array}{l}66 \mathrm{vvw} \\
86 \mathrm{vvw} \\
113 \mathrm{w}\end{array}$ & libr. $\mathrm{BrO}_{3}^{-}$ \\
\hline $125 \mathrm{w}$ & $\begin{array}{l}126 \mathrm{~ms} \\
146 \mathrm{~ms}\end{array}$ & rot. $\mathrm{BrO}_{3}^{-}$ \\
\hline $152 \mathrm{~ms}$ & $\begin{array}{l}156 \mathrm{~m} \\
163 \mathrm{~m}\end{array}$ & \\
\hline $200 \mathrm{vw}$ & $\begin{array}{l}199 \mathrm{~m} \\
218 \mathrm{~m} \\
236 \mathrm{~m} \\
251 \mathrm{~m} \\
260 \mathrm{~m} \\
295 \mathrm{~m}\end{array}$ & \\
\hline $\begin{array}{l}371 \mathrm{~ms} \\
383 \mathrm{sh}\end{array}$ & $\begin{array}{c}363 \mathrm{vvs} \\
389 \mathrm{~s}\end{array}$ & $v_{4} \mathrm{BrO}_{3}^{-}$ \\
\hline $429 \mathrm{vw}$ & $522 \mathrm{w}$ & $v_{2} \mathrm{BrO}_{3}^{-}$ \\
\hline $\begin{array}{l}760 \mathrm{sh} \\
784 \mathrm{vs} \\
796 \mathrm{sh}\end{array}$ & 789 vs & $v_{1} \mathrm{BrO}_{3}^{-}$ \\
\hline \multirow[t]{2}{*}{820 vs } & $\begin{array}{l}821 \mathrm{sh} \\
1026 \mathrm{sh}\end{array}$ & $v_{3} \mathrm{BrO}_{3}^{-}$ \\
\hline & $1597 \mathrm{~s}$ & $v_{2} \mathrm{H}_{2} \mathrm{O}$ \\
\hline \multirow{6}{*}{$\begin{array}{c}2050 \mathrm{~m} \\
2122 \mathrm{~ms} \\
2204 \mathrm{~m}\end{array}$} & $2075 \mathrm{w}$ & Res.Raman \\
\hline & $2857 \mathrm{vvw}$ & \\
\hline & $2992 \mathrm{vvw}$ & \\
\hline & $3155 \mathrm{sh}$ & $v_{1}-v_{3} \mathrm{H}_{2} \mathrm{O}$ \\
\hline & 3458 vvs br & \\
\hline & $3521 \mathrm{sbr}$ & \\
\hline
\end{tabular}

vvw, very very weak; vw, very weak; w, weak; wsh, weak shoulder; sh, shoulder; br, broad; vs, very strong; s, strong; vvs, very very strong; ms, moderately strong; m, moderately; sbr, strong and broad; rot., rotational; libr., librational.
In the stretching mode region of $\mathrm{H}_{2} \mathrm{O}$ a broad band extending from $3000-3708 \mathrm{~cm}^{-1}$ is obtained in the IR spectrum (Figure 4) with shoulder at 3155 and followed by in tense peaks 3458 and $3521 \mathrm{~cm}^{-1}$. In the bending mode region, a moderately intense band is observed at $1597 \mathrm{~cm}^{-1}$ in the IR spectrum. The appearance of $\mathrm{OH}$ stretching modes at lower wavenumber than those of free state values of $\mathrm{H}_{2} \mathrm{O}$ indicate the presence of hydrogen bonds in the crystal [24]. Due to hydrogen bonds, $\mathrm{OH}$ bending modes are usually expected to shift upwards. But the coordination of Thorium atoms to the water Oxygen atoms causes a downward shift. Therefore, this almost equally energetic upward and downward pulling of $\mathrm{O}$ atoms causes the intense $\mathrm{OH}$ bending modes to appear without any shift in wavenumber values with respect to its free state value $\left(1595-v_{2} \mathrm{H}_{2} \mathrm{O}\right)$. The appearance of additional bands in the $\mathrm{OH}$ stretching regions and broad spectral profile of both bending and stretching regions confirms the existence of hydrogen bonds of different strengths in the crystal [24,25]. The bands observed below $250 \mathrm{~cm}^{-1}$ are mostly of lattice modes and are assigned in Table 2. Interestingly, majority of the Raman and IR bands are not coinciding each other which indicate that the hydrated thorium bromate is crystallized in centrosymmetric space group which is in agreement with X-ray crystallographic information.

The strong Raman bands observed at 2130 and 2206 $\mathrm{cm}^{-1}$ probably attributed to resonance Raman scattering process since there is no vibrational bands are expected in this region for the title compound. Thorium is having closely lying "fo" electronic energy levels, the electronic transitions between these levels initiate the formation of bands in the region $1925-2280 \mathrm{~cm}^{-1}$ similar to that reported previously in several U(IV) and $\mathrm{Zr}(\mathrm{IV})$ bis (ketimide) complexes, and in a few Th(IV) compounds $[28,29]$.

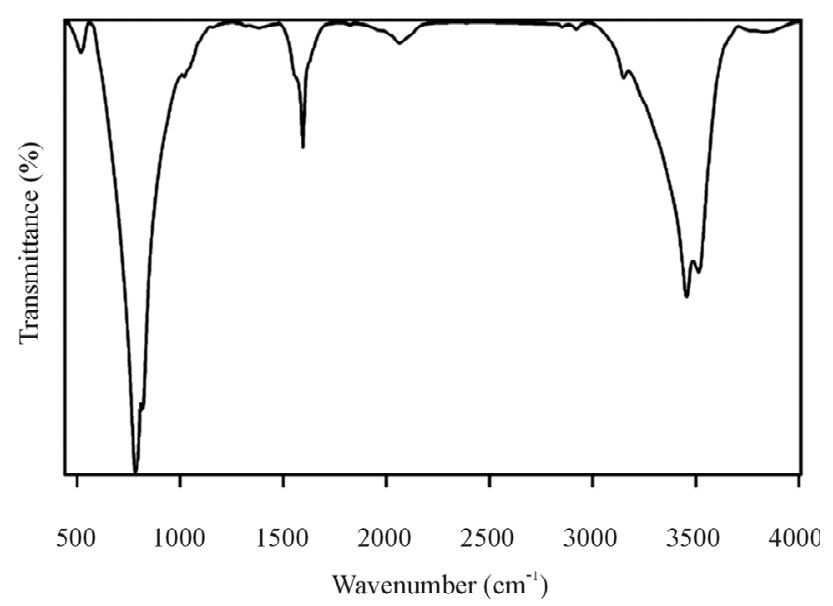

Figure 4. FTIR spectrum of the hydrated thorium bromate in the region $500-4000 \mathrm{~cm}^{-1}$. 


\section{Conclusion}

The crystal structure of hydrated thorium bromate shows the $\mathrm{Br}(1)-\mathrm{O}(1)$ distance is $1.6504(0.0133) \AA, \mathrm{Br}(1)-\mathrm{O}(2)$ $1.6712(0.0128) \AA$ and $\mathrm{Br}(1)-\mathrm{O}(3)$ is $1.6573(0.0129) \AA$. Additional bands obtained in the vibrational spectra in the region of $v_{1}$ modes in the thorium bromate hydrate are due to the lifting of degeneracy of $\mathrm{BrO}_{3}^{-}$ion, which occupies a site of lower symmetry than its free state at $\mathrm{C}_{3 \mathrm{v}}$. The lifting of degeneracy of $v_{4}$ mode both in the Raman and IR spectra indicate the lowering of symmetry of $\mathrm{BrO}_{3}^{-}$anion from $\mathrm{C}_{3 \mathrm{v}}$ pyramidal to lower one. The shifting of stretching modes of water towards low wavenumber region as compared to that of its free state value and the broadening of the stretching bands of $\mathrm{H}_{2} \mathrm{O}$ indicate the presence of hydrogen bonds of varying strengths in the crystal. Non-coincidence of majority of Raman and IR bands confirms the centrosymmetric space group P21/c of the crystal. Resonance Raman scattering process is seen in addition to vibrational bands attributed to closely lying "f" electronic energy levels. The present compound may be useful to study as a chemical oscillator and chemiluminescence systems in future.

\section{REFERENCES}

[1] S. K. Misra and X. Li, "Electron Paramagnetic Resonance of $\mathrm{Gd}^{3+}$-Doped $\mathrm{Dy}\left(\mathrm{BrO}_{3}\right)_{3} \cdot 9 \mathrm{H}_{2} \mathrm{O}$ and $\mathrm{Eu}\left(\mathrm{BrO}_{3}\right)_{3} \cdot 9 \mathrm{H}_{2} \mathrm{O}$ Single Crystals: Structural Phase Transitions and SpinHamiltonian Parameters," Journal of Physics: Condensed Matter, Vol. 4, No. 13, 1992, pp. 3559-3670. doi:10.1088/0953-8984/4/13/025

[2] D. Neogy and T. Purohit, "Magnetic Behavior and Crystal Field of $\mathrm{Dy}\left(\mathrm{BrO}_{3}\right)_{3} \cdot 9 \mathrm{H}_{2} \mathrm{O}$," Physical Review B, Vol. 35, No. 11,1987 , pp. 5849-5855. doi:10.1103/PhysRevB.35.5849

[3] N. Matsuyama, N. Okazaki, Y. Tanimoto and I. Hanazaki, "Photo-Response of the Bromate-Sulfite Chemical Oscillator with Tris-(bipyridine)ruthenium(II) as a Catalyst," Chemical Physics Letters, Vol. 323, No. 3, 2000, pp. 372-376. doi:10.1016/S0009-2614(00)00507-8

[4] K. Kurin-Csörgei, I. R. Epstein and M. Orbán, "Systematic Design of Chemical Oscillators Using Complexation and Precipitation Equilibria," Nature, Vol. 433, No. 7022, 2005, pp. 139-142. doi:10.1038/nature03214

[5] M. Iranifam, M. A. Segundo, J. L. M. Santos, J. L. F. C. Lima and M. H. Sorouraddin, "Oscillating Chemiluminescence Systems: State of the Art," Luminescence, Vol. 25, No. 6, 2010, pp. 409-418. doi:10.1002/bio.1203

[6] S. Pääkkönen, J. Pursiainen and M. Lajunen, "Fast Oxidation of Secondary Alcohols by the Bromate-Bromide System Using Cyclic Microwave Heating in Acidic Water," Tetrahedron Letters, Vol. 51, No. 51, 2010, pp. 66956699. doi:10.1016/j.tetlet.2010.10.009

[7] D. Deepa and G. Chandramohan, "Kinetic and Mechanistic Study on the Oxidation of Indole-3-Propionic Acid in
Acetic Acid Medium," Research Journal of Chemical Sciences, Vol. 2, No. 10, 2012, pp. 70-74.

[8] M. R. Shishehbore, A. Sheibani and M. Eslami, "Thionine-Bromate as a New Reaction System for Kinetic Spectrophotometric Determination of Hydrazine in Cooling Tower Water Samples," Journal of Chemistry, Vol. 2013, 2013, pp. 1-5.

[9] J. Albertsson and I. Elding, "The Geometry of the Nonaaqualanthanoid (3+) Complex in the Solid Bromates and Ethyl Sulphates," Acta Crystallographica, Vol. B33, 1977, pp. 1460-1469.

[10] H. Poulet, J. P. Mathieu, D. Vergnat, B. Vergnat, A. Hadni and X. Gerbaux, "Vibrational Spectra, Structure, and Phase Transition in Neodymium and Gadolinium Bromate Enneahydrates," Physica Status Solidi, Vol. 32, No. 2, 1975, pp. 509-520. doi:10.1002/pssa.2210320221

[11] R. E. Gerkin and W. J. Reppart, "The Structures of the Lanthanide Ethyl Sulfate Enneahydrates, $\mathrm{M}\left(\mathrm{C}_{2} \mathrm{H}_{5} \mathrm{SO}_{4}\right)_{3} .9 \mathrm{H}_{2} \mathrm{O}[\mathrm{M}=\mathrm{La}-\mathrm{Lu}($ except Pm) $]$, at $171 \mathrm{~K}$," Acta Crystallographica, Vol. C40, No. 5, 1984, pp. 781786.

[12] R. E. Gerkin and W. J. Reppart, "Structures of Holmium Bromate Enneahydrate at 168 and $294 \mathrm{~K}$ and Their Implications for the Isomorphic Series of Rare-Earth Bromate Enneahydrates," Acta Crystallographica, Vol. C43, No. 4, 1987, pp. 623-631.

[13] A. C. Blackburn, J. C. Gallucci and R. E. Gerkin, "The Structure of Hexaaquaaluminium(III) Bromatetrihydrate, $\left[\mathrm{Al}\left(\mathrm{H}_{2} \mathrm{O}\right)_{6}\right]\left(\mathrm{BrO}_{3}\right)_{3} \cdot 3 \mathrm{H}_{2} \mathrm{O}, "$ Acta Crystallographica, Vol. C48, No. 7, 1992, pp. 1185-1188.

[14] K. Lieselotte, L. K. Templeton and D. H. Templeton, "Structure of Barium Bromate Monohydrate," Acta Crystallographica, Vol. C45, No. 4, 1989, pp. 672-673.

[15] A. Abbasi and L. Eriksson, "Nonaaquayttrium(III) Tris(Bromate)," Acta Crystallographica, Vol. E62, No. 5, 2006, pp. 126-128.

[16] A. C. T North, D. C. Philips and F. S. Mathews, "A Semi-Empirical Method of Absorption Correction," Acta Crystallographica, Vol. A24, No. 3, 1968, pp. 351-359.

[17] Enraf-Nonius, "CAD-4 Software. Version 5.0.," EnrafNonius, Delft, 1994.

[18] T. Ueki, A. Zalkin and D. H. Templeton, "Crystal Structure of Thorium Nitrate Pentahydrate by X-Ray Diffraction," Acta Crystallographica, Vol. 20, No. 6, 1966, pp. 836-841. doi:10.1107/S0365110X66001944

[19] W. G. Fateley, F. R. Dollish, N. T. McDevitt and F. F. Bentley, "Infrared and Raman Selection Rules for Molecular and Lattice Vibrations-The Correlation Method," Wiley-Interscience, New York, 1972.

[20] K. Nakamoto, "Infrared and Raman Spectra of Inorganic and Coordination Compounds-Part A," 5th Edition Wiley-Interscience, New York, 1997.

[21] D. M. Adams, J. Barlow, H. Tan and M. J. Taylor, "The Vibrational Spectra of Mercury (I) Bromate, Sulphate, and Nitrate Dihydrate," Journal of Raman Spectroscopy, Vol. 5, No. 1, 1976, pp. 63-73. doi: $10.1002 /$ jrs. 1250050108 
[22] R. S. Jayasree, M. J. Bushiri, A. John and V. U. Nayar, "Temperature Dependent Polarized Raman Spectra of Nonaaqualanthanoid (Pr) Single Crystal," Spectrochimica Acta, Vol. A64, No. 2, 2006, pp. 518-525.

[23] T. Devanathan and T. K. K. Srinivasan, "Raman Spectra of Single-Crystal $\mathrm{Cd}\left(\mathrm{BrO}_{3}\right)_{2} \cdot 2 \mathrm{H}_{2} \mathrm{O}$ and Polycrystalline $\mathrm{Cd}\left(\mathrm{BrO}_{3}\right)_{2} \cdot 2 \mathrm{D}_{2} \mathrm{O}$," Journal of Raman Spectroscopy, Vol. 18 , No. 7, 1987, pp. 525-531. doi:10.1002/jrs.1250180714

[24] T. K. K. Srinivasan and T. Devanathan, "Raman Spectral Studies of Dehydration of $\mathrm{Sr}\left(\mathrm{BrO}_{3}\right)_{2} \cdot \mathrm{H}_{2} \mathrm{O}$," Journal of Raman Spectroscopy, Vol. 21, No. 2, 1990, pp. 99-102. doi:10.1002/jrs.1250210206

[25] M. J. Bushiri and V. U. Nayar, "Raman and FTIR Spectra of $\left[\mathrm{Cu}\left(\mathrm{H}_{2} \mathrm{O}\right)_{6}\right]\left(\mathrm{BrO}_{3}\right)_{2}$ and $\left[\mathrm{Al}\left(\mathrm{H}_{2} \mathrm{O}\right)_{6}\right]\left(\mathrm{BrO}_{3}\right)_{3} \times 3 \mathrm{H}_{2} \mathrm{O}$," Spectrochimica Acta, Vol. A58, No. 5, 2002, pp. 899-909.

[26] M. J. Bushiri and V. U. Nayar, "Raman and FTIR Spectra of $\mathrm{RE}\left(\mathrm{BrO}_{3}\right)_{3} \cdot 9 \mathrm{H}_{2} \mathrm{O}(\mathrm{RE}=\mathrm{Eu}, \mathrm{Tb})$ and Electronic Transi- tions in $\mathrm{Eu}\left(\mathrm{BrO}_{3}\right)_{3} \cdot 9 \mathrm{H}_{2} \mathrm{O}$," International Journal of Modern Physics, Vol. B15, No. 18, 2001, pp. 2499-2507.

[27] A. Viste and D. E. Irish, "Raman and Infrared Spectral Studies of Polycrystalline Thallium(I) Halates, $\mathrm{TlXO}_{3}$," Canadian Journal of Chemistry, Vol. 55, No. 18, 1977, pp. 3218-3227. doi:10.1139/v77-448

[28] E. J. Schelter, P. Yang, B. L. Scott, R. E. Da Re, K. C. Jantunen, R. L. Martin, P. J. Hay, D. E. Morris and J. L. Kiplinger, "Systematic Studies of Early Actinide Complexes: Thorium(IV) Fluoroketimides," Journal of the American Chemical Society, Vol. 129, No. 16, 2007, pp. 5139-5152. doi:10.1021/ja0686458

[29] D. E. Morris, R. E. Da Re, K. C. Jantunen, I. C. Rodriguez and J. L. Kiplinger, "Trends in Electronic Structure and Redox Energetics for Early-Actinide Pentamethylcyclopentadienyl Complexes," Organometallics, Vol. 23, No. 22, 2004, pp. 5142-5153. doi:10.1021/om049634v 